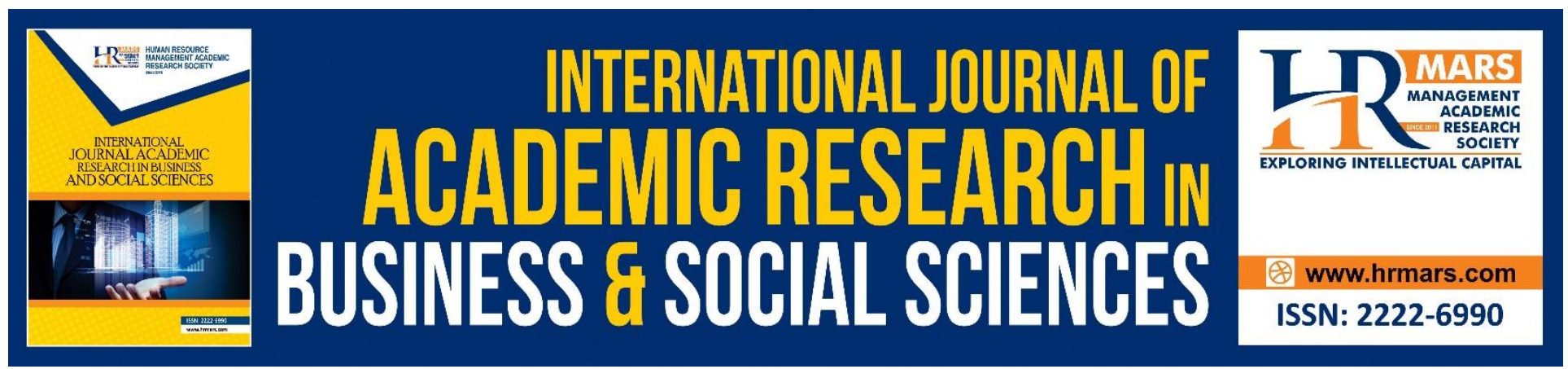

\title{
Compensation as an Inducing Factor for Employee Performance in Customer-Contact Businesses
}

\author{
Sunday Ewah and Joseph E. Osang
}

To Link this Article: http://dx.doi.org/10.6007/IJARBSS/v8-i9/4634

DOI: $10.6007 /$ IJARBSS/v8-i9/4634

Received: 03 August 2018, Revised: 27 August 2018, Accepted: 29 Sept 2018

Published Online: 20 October 2018

In-Text Citation: (Ewah \& Osang, 2018)

To Cite this Article: Ewah, S., \& Osang, J. E. (2018). Compensation as an Inducing Factor for Employee Performance in Customer-Contact Businesses. International Journal of Academic Research in Business and Social Sciences, 8(9), 524-536.

Copyright: (C) 2018 The Author(s)

Published by Human Resource Management Academic Research Society (www.hrmars.com)

This article is published under the Creative Commons Attribution (CC BY 4.0) license. Anyone may reproduce, distribute, translate and create derivative works of this article (for both commercial and non-commercial purposes), subject to full attribution to the original publication and authors. The full terms of this license may be seen at: http://creativecommons.org/licences/by/4.0/legalcode

Vol. 8, No. 9, September 2018, Pg. 524 - 536

Full Terms \& Conditions of access and use can be found at http://hrmars.com/index.php/pages/detail/publication-ethics 


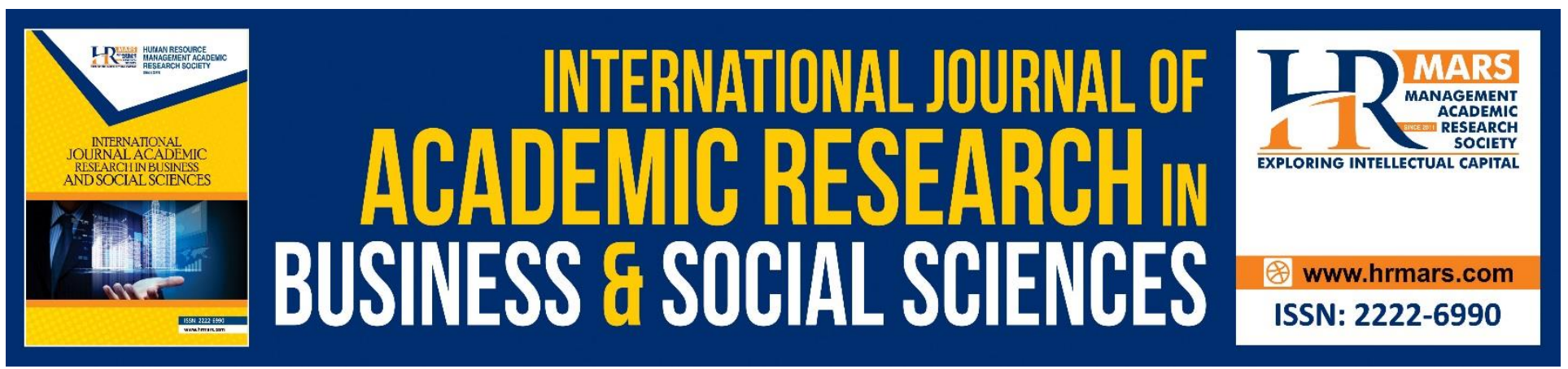

\title{
Compensation as an Inducing Factor for Employee Performance in Customer-Contact Businesses
}

\author{
Sunday Ewah, Ph.D and Joseph E. Osang \\ Ccross River Unversity of Technology, Faculty of Management Sciences, Ogoja Campus. Nigeria \\ Email: soniewah@yahoo.com
}

\begin{abstract}
The study takes a critical look on compensation as one of those inducing factors that influence employee performance in customer-contact businesses in Nigeria. To solve the problem of the study questions were formulated in questionnaires and administered on employees and customers of 10 different hotels and in five cities in Nigeria. The model specific for the test of hypothesis was Pearson Product Moment Correlation Coefficient. The result of the study showed that the take home pay of workers is not commensurate to the service or work performed. Moreover employees do not like working in hotels were their optimal performance is not compensated, this was confirmed when the test of hypothesis was carried out. From the study it was also discovered that the lack of incentive and appropriate compensation contributes to high quit rate among hotel employees. If the workers are motivated, they will serve customers better and it will spur future purchase decision accordingly. Furthermore, findings indicated that hoteliers are more profit oriented; hence it was concluded and recommended that employers in the industry should try as much as possible to adopt a compensation method that is commensurate to prevailing economic situations in Nigeria
\end{abstract}

Keywords: Compensation, Employer, Employee, Hotel, and Job Performance

\section{INTRODUCTION}

Given the increasingly volatile and complex socio-economic structure of business organizations and general proliferation of hotel services in Nigeria, it has become increasingly necessary to pay more attention to the performance of employee of these service units. To motivate employees' performance and enhance customer satisfaction, a reasonable number of hotel businesses in developed societies have moved from traditional behaviour-based fixed salaries to outcome-based contingent compensation (Bivins, 1989 and other scholars). A vital ingredient of excellent service quality is hiring highly motivated employees and rewarding their performance (Zeithaml, et al, 1993). Most successful hoteliers focus their attention on products (which are tangible and intangible), customers and employees. The result of this effort is often success and profitability as a going concern. In order to achieve predetermined objectives as put in place by stakeholders, it is pertinent 
that hotel businesses should include in their corporate strategy, high-involvement practices. This implies helping employees developed the kind of company or hotel specific human capital knowledge that would improve performance and work processes for the benefit of all. Human capital is the productive skills and degree of knowledge possessed by an individual employee that enables him to interact effectively with customers. This is imperative since customer-contact employees manage the boundary between the company and its customers (Mills, et al, 1983) and the behaviour of these employees shape customers buying behaviour. To persuade customers to buy and enjoy the services or products of any of the hotel units., employees need a clear understanding of specific product features, services agreements, pricing policy, packaging, promotions for particular customers segments, legal regulations, demand characteristics and knowledge to negotiate customized offering, among others. These laudable heights can only be attained and achieved if the workforce is well motivated. If the compensation and incentive structure is commensurate to the work done, then the objectives will be attained, otherwise the reverse is the case.

Thus it has become a widely held premise that people who work as employees of most organizations (including hotels) provide them with important sources of sustainable competitive advantage (Prahalad, 1983; Pfeffer, 1994 and many others) and that the effective management of employees in these organizations will definitely contribute to their performance. Accordingly, hotel employers have to harness the productive potentials of their employees to achieve superior performance.

A large body of research indicates that the distribution of rewards within an organization is fundamental to employee attitudes and behaviours, such as job-related satisfactions, organizational commitment and withdrawal, and job performance (Folger and Cropanzano, 1998). This evidence showed that people are more concerned about how their rewards compare to those of relevant others than about absolutes amount of rewards they receive. This is because reward distributions signal an individual's relative performance proficiency and his/her organizational value or status (Frank, 1994).

In work organizations compensation is the primary reward employees receive. More contemporary theories have asserted that decision about pay dispersion are among the most important decisions facing compensation policy makers, because dispersion influences how hard people work, the kind of human capital they will acquire and whether they leave or stay with an organization (Lazear and Rosen, 1981, Mahoney, 1979). This is true because hotels and organizations can adopt various human resource management practices to enhance employee skills and performance while performing their functional roles. The ability of employees to function will be limited if they are not motivated to perform their jobs. The form and structure of an organization's reward practices can affect employee motivation and performance levels in several ways. First, hotels can implement merit pay or incentive compensation systems that provide rewards to employees for attaining specific goals (Delaney and Huselid, 1996). A substantial body of evidence has focused on the impact of incentive compensation and performance management systems on firm performance (Gerhart and milkovich, 1992).

Moreover, the way in which a workplace is structured affects organizational performance to the degree that skilled and motivated employees are directly involved in determining what work is performed and how this get accomplished. Employee participation system (Wagner, 1994), internal labour markets that provide an opportunity for employees to advance within a firm (Osterman, 1987) 
and employee participation and empowerment, extensive training and performance based production incentive compensation, are widely believed to improve the performance of employee in service organizations (Pfeffer, 1994). It is quite unfortunate that much is expected from customerscontact employees in terms of input, with little or nothing to show for the many hours spent daily on the job. The fate of workers in most hotel businesses (especially those privately own) in Nigeria is better imagined than experienced. The owners of these hotels are more or less exploiters and profit oriented. They have no pity for their employees. Their salaries are too poor and sometimes they owe their employees for months without being paid. This has resulted to the incessant quit rate in some of these service units. Studies have clearly shown that in customers -contact settings, high quit rates not only increase the cost of recruitment and selection of new employees, but negatively affect performance and sales growth. This is because new employees face a learning process or curve. Longterm employees have the tacit company specific skills and knowledge, often needed to more effectively serve customers and enhance their performance vis-a-vis, hotelier's expectations. Therefore for the companies to continue benefiting, it is necessary that employers should do their possible best to maintain a steady workforce within the industry. This is because it is the human element that coordinates every other factor of production or resources.

The rest of the article is organized as follows; review of related literature, employee compensation, determinant of employee compensation in customer-contact service, methodology, data analysis and discussion of findings, test of hypothesis, summary and conclusion, and recommendations.

\section{Review of Related Literature}

In most cases financial compensation are made or paid to employees for rendering their services in a work environment. The quantum of these financial rewards, its regularity and perceived fairness by all is critical factor in compensation management, in view of the fact that financial remuneration plays a significant role in the socio-economic and psychological well being of the individual employee (Banjoko, 2000). Employees' wages and salaries and the various benefits that are embedded or packaged serve as key factors in attracting, retaining, and motivating the employees towards higher performance in customer-contact industry. According to Flippo, (1996) employees' compensation is design to attract capable employees to the organization, to motivate employees towards superior performance and retain their services over an extended period of time. This is even more so in Nigeria where employees of one hotel business compare it with what is obtainable in another within the same locality. The payment of salaries and wages is an indication of effective transaction between the employees and employers in which there has been an exchange of labour or services. In order to encourage workers to put in more effort on the job, performance incentives are given to them in some organizations. These are payments made to employees based on the results achieved, either

in attracting more customers to the customer-contact unit or by offering unique services that are quantifiable and result to profit.

The use of performance incentives is premised on the belief that output can be measured and that frequent and increase pay can tied to increased performance on the part of employees of hotel businesses in Nigeria. Frederick Winslow Taylor greatly supported the use of this method when he said that workers would always exert greater efforts if they are given incentives (Bartel, 1994). 


\section{EMPLOYEE COMPENSATION}

The only way a worker can show for his or her contribution in a work environment is how much he is paid. Consequently, it is expected that the remuneration will better off both employees' psychological temperament and socio-economic life (Bailey, 1993). Quite often, remuneration and other incentives serve as instrument for inducing desired performance level and an instrument for avoiding unpleasant psychological problems that may affect workers in service units. Looking at it from the socio-economic perspective, workers salary is a status symbol and a major determinant of their purchasing power, and continuous stay in the company. Hence it has a major influence on other macro-economic variables.

Given the foregoing specific importance of remuneration to employees, hotelier should device an effective compensation packages that meets the expectation and aspirations of their workers as well as satisfy their own profitability and growth objectives. This is because employee remuneration package and other forth coming incentives are major factors in attracting, retaining and motivating good performance, that would give a particular hotelier competitive edge. Though it is the most single expensive item of cost, hence the need to ensure efficient management. This can be achieved by ensuring that employees are rewarded based on services actually performed. Banjoko (2000) enunciated that, an effective compensation management is desirable in view of the following consideration;

- It performs a labour market function by helping to allocate potentially skilled individuals among companies in accordance with the perceived attractiveness of jobs as expressed by the pay offers of these competing companies or hotels.

- It helps to keep employees contented, minimize employees' complaints and grievance that may be related to inadequate or inequitable pay level among different service units.

- It helps to reassure employees that pay policies are fair and will apply across board uniformly and consistently with no regards for favourism or discrimination, and in line with government stipulations.

- It helps in the application of the principle of reward and sanction to employees who identify with the company on one hand and those who defy company rules.

Efficiency wage theory posits that employees with high relative pay and low performance monitoring will be more productive in order to avoid the prospect of a worse job on the external market (Krueger and Summers, 1987).

Finally, employee incentive such as training, employment security, high relative pay, and practices that build trust induce employee performance, attachment and commitment in a particular hotel business or organization. Some empirical research have shown significant negative relationship between individual turnover and employment security measure at an individual level (Cotton and Tuttle, 1986) and (Shaw et al, 1998) and between turnover and higher compensation levels (Leonard, 1997); and Powell, et al 1994).

\section{DETERMINANTS OF EMPLOYEE COMPENSATION IN CUSTOMER-CONTACT SDERVICE}

The performance of an employee as earlier said is tied to what he or she receives as take home package. This can be represented in econometric form as;

$Y=f(X 1, X 2, X 3, X 4, X 5, X 6, X 7$, Xn. 
Where; $Y$ represents compensation $(C p)$ or dependent variable

$\mathrm{X} 1$ to $\mathrm{X} 7$ are independent variables that are most likely to

Determine how individual employees will be compensated.

$F$ is the functional notation.

Equation (1) can be specifically stated as;

$\mathrm{Cp}=\mathrm{F}(\mathrm{Lm}, \mathrm{Pl}, \mathrm{Hp}, \mathrm{Cl}, \mathrm{Cb}, \mathrm{Pw}, \mathrm{Gr})$.

Where; $\mathrm{Lm}=$ Labour market

$\mathrm{PI}=$ Productivity level

$\mathrm{Hp}=$ Hotel's ability to pay $\quad-\quad \mathrm{X} 3$

$\mathrm{Cl}=$ Cost of living $\quad-\quad X 4$

$\mathrm{Cb}=$ Collective Bargaining $\quad-\quad \mathrm{X} 5$

$\mathrm{Pw}=$ Prevailing wage rate $\quad-\quad \mathrm{X} 6$

$\mathrm{Gr}=$ Government regulations $\quad-\quad X 7$

Assuming there is the need to apply Ordinary Least square

(OLS) Linear regression equation based on the above functional

Relation, it will become;

(OLS) Linear regression equation based on the above functional

Relation, it will become;

$\mathrm{Y}=\mathrm{a} 0+\mathrm{b} 1 \mathrm{X} 1+\mathrm{b} 2 \times 2+\mathrm{b} 3 \times 3+\mathrm{b} 4 \times 4+\mathrm{b} 5 \times 5 \times b 6 \times 6+b 7 \times 7+\mathrm{U}$

Note that ' $a$ ' and ' $u$ ' in equation (3) represent the regression

Constant and the error term or stochastic error term respectively.

Combining equation (2) and ( 3 ) gives the following;

$C p=f(a 0+b 1 L m+b 2 \mathrm{Pl}+b 3 \mathrm{Hp}+b 4 \mathrm{Cl}+\mathrm{b} 5 \mathrm{Cb}+\mathrm{b} 6 \mathrm{Pw}+\mathrm{b} 7 \mathrm{Gr}+\mathrm{U})$

Transforming equation (4) to natural logarithm, we obtain;

$\log C p=a 0+b 1 \log L m+b 2 \log P I+b 3 \log H p+b 4 \log C l+b 5 \log C b+b 6 \log P w+P 7 \log G r+U \ldots . . \quad 5$

In order to make it easier to comprehend to all who may use this study, the factors are carefully explained below:

Labour Market (Lm): With the increase in the number of hotel businesses spread all over the geopolitical zones in Nigeria, the demand for workers in all service units has increased tremendously. This requires highly motivated and result oriented individuals to be considered for employment, and their acceptance will be subject to a compensation that is commensurate to their performance, therefore the higher the pay and incentive, the higher the input or willingness to work and vice-versa. Productivity Level (PI): It is measured in terms of what is generated in the form of revenue to the hotel after a period of time. Hence the amount paid to employees as compensation for performing their job reflect and contribute to their performance, steady mentality and temperament to continue working for the company.

Hotel Ability to Pay (Hp): Some hotels in Nigeria have the strong financial muscles to pay reasonable amount that is encouraging to their workers, but the bulk of them in the organized private sector are not encouraging their workers. They pay between ten to twenty thousand Naira to an averagely educated worker, apart from those very few that are owned by the state. The more reason most people in this part of the world prefer working with the government (Ubeku, 1975). 
Cost of Living $(\mathbf{C l})$ : The economic down-turn of things generally calls for the need to review and restructure the take home pay of an average hotel worker. This will enhance and contribute to his aggregate performance and willingness to attend to customers' needs. But where the salary is nothing to write home about, there is disincentive to work in such places, while those already working have the intention to quit as soon as they come by better jobs.

Collective Bargaining (Cb): It is quite unfortunate that most workers in privately owned hotels in Nigeria do not have organized Unions; this makes it imperatively difficult for them to come together as a body to demand for improved remuneration and other conditions that will improve their performance and satisfaction. Remember that, these customer-contact service employees' deal directly with final consumers who patronize their products and if they are dissatisfied, it may affect the way they attend to customers. Moreover, customers that receive shabby treatments may not come back to the same hotel to lodge or do other businesses. Therefore, employers should sit at a round table with their employees once in a while to discuss terms in the form of collective bargaining. This will result to better compromise.

Prevailing wage (Pw): There is no standard wage rate system among hotel businesses in Nigeria. Most of them operate different salary structure; which are often determined by the employers solely. While the employees act as the receiving party.

Government Regulations (GR): Though the government has put in place laws that protect employees from malicious attitude of employers in the private sector, yet employers sometimes contravene such laws. These laws include Equal Pay Act, the Fair Labour Standard Act and the Equal Pay for Equal Work Act, etc. To worsen the situation those authorized to enforce the implementation of such laws neglect their duties. At the end of day employees have to survive at the mercy of employers' dictated compensation or remuneration that is not commensurate to the work perform (Oni, 1977).

\section{METHODOLOGY}

The study followed the basic tenets of a naturalistic inquiry and was guided primarily by the approach suggested by Glaser and Strauss 1967 . The approach comprises the discovery of important categories and their properties, condition and consequences through the constant comparative method and conceptualization. Thus sampling was done to select participant or employees of 10 different service units or hotels in five cities in Nigeria that exemplify the characteristics of interest. From these service units the total number of employee who were interviewed using questionnaires as the measuring instrument numbered up to 1020, from basically privately owned hotels.

Generally, behavioural research measure (such as the type used in this research) are seldom, if ever totally reliable and valid, but the extent of their validity and reliability must be evaluated if the research question is to be truly seen as scientific. Therefore, all the data collected were analyzed and the core model specification for the test of hypothesis formulated was the Pearson Product Moment Correlation Coefficient. Its value is between -1 and +1 , that is $-<r<r+1$ and it is given below

$$
r \models \frac{n \cdot \sum x y-\sum x \cdot \sum y}{\left[x^{2}-\left(\sum x\right)^{2}\right]\left[n \cdot \sum y^{2}-\left(\sum y\right)^{2}\right.}
$$

Where $r$ correlation coefficient, $y$ and $x$ are the variables of interest, $n$ number of hotels. Test of significant ${ }^{\prime} \mathrm{t}^{\prime}=$

$$
\frac{r \sqrt{n-2}}{1-r 2}
$$




\section{Data Analysis and Discussion of Findings}

Table 1; Shows the number of respondents that were administered questionnaire in five major cities, housing ten different service units or hotels in Nigeria.

Calabar has the highest number of respondents in four different service units. When the figures were added, the result is 450 (41.1\%) respondents. This is followed by Enugu, with total of 360 (35.3\%) respondents, those that answered questions in Ogoja axis were 90 (8.8\%), while Ikom and Abuja had $70(6.7 \%)$ and $50(4.9 \%)$ response rates respectively. In conclusion, the majority response rate in Calabar may not be unconnected with the large number of hotels spread all over the town. This could be as a result of the state being tourist centre and the presence of Tinapa.

In question one from table 2, it was observed that majority, that is 700 (68.8\%) of the respondents said yes to the research question. 320 (31.4\%) replied no to the research question. This means that the take home pay of hotel workers was not commensurate to the work they perform routinely. This is mostly peculiar with privately owned hotels or services units.

From question two in the same table it was observed that $410(40.2 \%)$ respondents gave a positive response, while 610 (59.8\%) gave negative response. Thus it can be inferred that most hoteliers find it difficult to give fridge benefits to their employees, despite attaining set target or benchmark. This is really not a welcomed development in customer-contact service units, because it discourages hard work and creativity amongst employees.

Responses in question three indicate that 760 (74.5\%) of those that answered the questions in the questionnaire responded in the affirmative, that employees' prefer working in service units/hotels where their optimal performance will be appreciated and compensated. The remaining respondents that are 260 (25.5\%) gave negative responses. That result showed that majority of the respondents supported the research question. This equally gives support to the work earlier carried out by Lazear and Rosen, in 1981; and Mahoney in 1979. Moreover the result was also confirmed when the test of hypothesis was carried out.

Results from question four showed that 915 (89.7\%) respondents gave positive response to the question that was asked. The other respondents; 105 (19.3\%) were not convinced, hence their negative responses. It then suffices to say that a well motivated worker will perform better and serve customers in customers-contact service units better. Numerous scholars have laid much emphasis on the need to motivate workers in order to increase the productivity of such employees in a work environment, and it is consistent with the earlier work of Frank in 1994.

Question five clearly showed that the services of workers in a particular hotel determined customers' future response and patronage of such service unit based on $650(63.7 \%)$ respondents who answered yes to the question. Those respondents that answered no to the research question were 370 (36.3\%). That means there is need to develop human capital knowledge that would improve employee performance and ability to serve and attend to customer needs in service units. This is premised on the philosophy of marketing, which says that, the essence of the existence of any business or organization is customer satisfaction first, before thinking of profit. Thus, a satisfied customer could mean repeat business or purchase with the same company or hotel in future.

Furthermore, question six indicates that 900 (88.2\%) of the respondents gave positive result, the remaining 120 (11.8\%) of the respondents gave negative result. Based on the majority response rate, 
it can be deduced that most of the hotel businesses (especially privately owned ones) are profitoriented. Despite the desire to make profit as a going concern, it is equally necessary to maintain a steady workforce that expects to benefit from the proceeds of their labour. This is because it is the employees that coordinate every other factor of production. Thus, hoteliers should maintain a balance.

Finally, question seven showed that 820 (80.4\%) of the respondents answered yes to the research question. Thus, they accept the fact that lack of incentives and appropriate compensation contributes to high quit rate amongst customer-contact employees or hotel industry in Nigeria. The more reason some workers and job seekers regard the industry as a stepping stone towards achieving and gaining better well paid jobs in future. Other respondents who gave negative responses were 200 (19.6\%). This was quite a negligible number of compared to the former.

\section{TEST HYPOTHESIS}

Ho: Employees will prefer to work in hotels or customer-contact services where their optimal performance is not well compensated.

H1: Employee will prefer to work in hotel or customer-contact services where their optimal performance is well compensated.

Decision: The result from test of hypothesis showed that the calculated value is 6.7, while the critical value 2.3, that ' $\mathrm{Ho}$ ' should be rejected and $\mathrm{H} 1$ should be accepted. The implication of this result is that employees will prefer working in service units or hotels were their optimal performance will be acknowledged and adequately compensated for work done.

\section{SUMMARY CONCLUSION}

The total number of respondents that answered the research questions was 1020 respondents drawn from ten service units in Calabar, Ikom, Ogoja, Enugu and Abuja all in Nigeria. But the bulk of response came from Calabar. Other phenomena questions that were asked showed that the take home pay that employees receive in most service units is not enough to take care of their needs. Moreover, they seldom give them fringe benefits even when they attain hoteliers' benchmark. It would have been more encouraging to introduce a wage system that has a human face and can afford to meet the challenges of high inflation rate in the country, since every worker both in private and public sector buy goods from the same market. The study also attests workers willingness to work in places their optimal performance will be recognized and compensated. This is because they believe that a well articulated compensation and other incentives and fringe benefits are the driving force that energizes and spurs actions, towards achieving the highest level of productivity. The study further affirmed that the interaction of customers and workers in hotel industry determines customers' subsequent decisions whether to visit and patronize the hotel or not. In a highly competitive world of today, it is more important for businesses to indicate and imbibe the culture of long-lasting relationship with customers. This can only be achieved if the human element is taken into consideration. Though, as a result of the profit oriented motive of some managers/directors, this goal remains a mirage according to the findings.

Finally, the study submits that the lack of incentives and appropriate compensation in most hotel businesses in Nigeria contribute to the high quit rate of workers within the industry. It is important 
to note that, the high quit rate in a particular industry or company is a disadvantage. This is because it delays the learning process of engaging new employees to do the job that the former workers were already acquainted with. Therefore there is the need to minimize workers mobility within the industry. This height can only be achieved if investor in the industry could make things happen in a way favourable to both parties (employers and employees), while Banjoko (2000) concluded in his work that customers benefit from every of their effort. The consequences of pay dissatisfaction are always dismal such that it could damage employees' morale and restrain the achievement of higher performance and productivity in customer-contact businesses. Therefore managers and stakeholders must strive towards resolving such problems and abnormalities.

\section{RECOMMENDATIONS}

1. Employers in the industry should try as much as possible to adopt and devise a unified salary structure or compensation method that is commensurate to the demand of contemporary society. This will help to reduce the quit rate currently experienced in the industry and maintain a steady work force that would enhance productivity and serve customers better.

2. Employees/workers on their part should come together as a unified body in the same industry across Nigeria, using their representatives to dialogue with employers for improvement that that can take care of their well being.

3. The government should step up action once more in order to re-enforce laws guiding the remunerations policy in the private sector thereby making it compulsory that such operators adhere to government policy concerning what an average employee is entitled to earn ( as take home pay within a given period). This will improve the poor pay scheme that is currently experienced by workers in these service units.

\section{REFERENCES}

Bailey, T. (1993) Discretionary Effort and the Organization of Work: Employees Participation and Work Reform Working Paper, Columbia University, New York.

Bartel, A.P. (1994) Productivity Gains from the Implementation of Employee Training Programmes. Industrial Relationship. 1994, 33: 411-425.

Banjoko, S.A. (2000) Human Resource Management: An Expository Approach. Sanban Publishers Ikorodu Road Lagos. Nigeria. First Edition

Bivins, J. (1989) Focus on Compensation. Store, 1989, 71 (90): 25-30.

Cotton, J. I. and Tuttle, J.M, (1986) Employee Turnover: A Meta - Analysis and Review with Implication for Research. Academy of Management Review, 11: 55-70

Delaney, J. t. and Huselid, M. A. (1996). The Impact of Human Resource Management Practice on Perception Of Organizational Performance. Academy of Management Journal Vol.39 No. 4, PP.949969

Flippo, E. P. (1986) Personnel Management: Mc Graw Hill series fifth Edition,

Folger and Cropanzona In Bloom, M. and Michel J. G. (2000). The Relationship Among Organizational Context Pay Dispersion, and Managerial Turnover. The Academy of Management Journal, 1998 Volume 45, Number 1, Pg: 33. 
Frank, (1984), In Bloom, M. and Michel J. G. The Relationship among Organizational Context, Pay Dispersion, and Managerial Turnover. The academy of Managerial journal, 2002. Volume 45, Number 1, Pp. 33.

Gerhart, B. and Milkovich, G. T.(1992) Employees Compensation. Research and Practice. In M. D. Dunnette and L. M. Hogh (Edss) Hand Book of Industrial and Organizational Psychology, (2 ${ }^{\text {nd }}$ Ed.), Vol 3: 481-569/ Palo Alto CA Consulting Psychologist Press.

Glaser and Strauss (1967) Impact of Valid Selection Procedures on Work-force Productivity. Journal of Applied Psychology, 64: 609-626.

Krueger, A. B. and Summers, I . H. (1987) Reflections on the Inter-industry Wage Structure. In K. Lang and J. s.Leonard (eds). Unemployment and the Structure of Labour Market: 17-47, New York: Blackwell.

Lazear and Rosen in Blooom, M and Michel J. G. (2002). The Relationship among Oraganizational Context Pay Dispersion, and Managerial Turnover. The Academy of Management Journal. 1981, Volume 45, Number 1, Pp. 33.

Leanard, J. S. Carrots and Sticks (1987): Pay Supervision and Turnover. Journal of Labour Economics. 5: $136-152$.

Mahoney in Bloom, M. and Michel J. G. (2002) The Relationship Among Organizational Context, pay Dispersion and Managerial Turnover. The Academy Of Management Journal, Volume 45, Number 1, Pp.33.

Mills, P. K, Chase, R. B. and Marguiles, N (1983) Motivating the Client/Employee system as a Service Production Strategy, Academy of Management Review, 8: 301- 310.

Oni. E. O. (1977) Money and the Motivation of Nigeria Workers. Labour and Society, Vol. 2 No.2 (April) Osterman, P. (1987) Choice of Employment System in Internal Labour Markets. Industrial Relations. 26:46-57.

Pfeffer, J. (1994) Competitive Advantage Through people. Boston; Harvard Business School Press.

Powerll, I. Montgomery, M. and Cosgrove, J. (1994) Compensation Structure and Establishment Quit and Fire Rates' Industrial Relation, 33: 229-348.

Prahala, C.K. (1983) Devdeloping Strateguc Capability: An Agenda for Top Management Human

Resource, 1983, 22: 237-254.

Shaw,J.D. Jenkins, and Gupta, N.(1998) An Organizational Level of Analysis Voluntary and Involuntary Turnover. Academy of Management Journal, 39: 1 - 15.

Ubeku A. K. (1975) Personnel Mangement in Nigeria. Ethiop Publishing Corporation Benin City Nigeria.

Wagner, J. A. (1994) Participations Effect on Performance and Satisfaction; A Reconsideration of Research Evidence. Academy of Management Review, 19; 312 - 320.

Zeithaml, V., Parasuranman , A. and Barry, L. I. (1993) Delivery Quality Service; Balancing Customers Perceptions and Expectation. New York; Free Press. 
INTERNATIONAL JOURNAL OF ACADEMIC RESEARCH IN BUSINESS AND SOCIAL SCIENCES Vol. 8, No. 9, Sept. 2018, E-ISSN: 2222-6990 @ 2018 HRMARS

Table3 Test of Hypothesis using Response to Question three in the Questionnaire

\begin{tabular}{|l|l|l|l|l|l|l|}
\hline S/N & $\begin{array}{l}\text { Sampled } \\
\text { Hotels }\end{array}$ & $\mathbf{Y}$ (yes) & $\mathbf{X}(\mathbf{N o})$ & $\mathbf{Y}^{\mathbf{2}}$ & $\mathbf{X}^{\mathbf{2}}$ & $\mathbf{Y X}$ \\
\hline 1 & Pyramid & 70 & 10 & 4900 & 100 & 700 \\
\hline 2 & Citaros & 80 & 20 & 6400 & 400 & 1600 \\
\hline 3 & Paradise & 60 & 10 & 3600 & 100 & 600 \\
\hline 4 & Channel view & 130 & 70 & 16900 & 4900 & 9100 \\
\hline 5 & Heritage & 60 & 10 & 3600 & 100 & 600 \\
\hline 6 & Plaza & 50 & 5 & 2500 & 25 & 250 \\
\hline 7 & Akuma Lodge & 30 & 5 & 900 & 25 & 150 \\
\hline 8 & Paradise & 140 & 60 & 19600 & 3600 & 8400 \\
\hline 9 & Presidential & 100 & 60 & 10000 & 3600 & 6000 \\
\hline 10 & Agura & 40 & 10 & 1600 & 100 & 400 \\
\hline & & $\Sigma=760$ & $\Sigma=260$ & $\sum=70,000$ & $\sum=12,950$ & $\sum=27800$ \\
\hline
\end{tabular}

Source: Researchers' Computation, 2017

$$
\begin{aligned}
& r=\quad 10 \times 27800-260 \times 760 \\
& \sqrt{\left[10 \times 12950-(260)^{2}\right]\left[10 \times 70,000-(760)^{2}\right]} \\
& r=\frac{278000-197600}{\sqrt{129500-67600 \cdot 700,000-577600}} \\
& r=\quad \underline{80400} \\
& \sqrt{61900 \times 122400}
\end{aligned}
$$

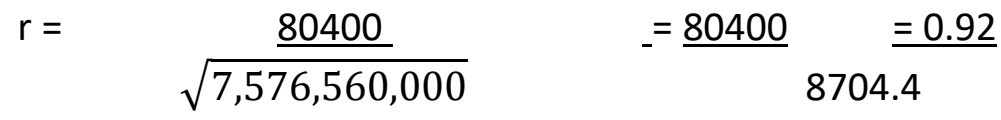

$$
\begin{aligned}
& r=0.92 \\
& \mathrm{t}=\quad 0.92 \frac{\sqrt{10-2}}{1-0.92^{2}} \quad 0.92 \frac{\sqrt{8}}{1-0.85} \\
& \mathrm{t}=0.92 \frac{\sqrt{8}}{0.15} \quad=\quad 0.92 \sqrt{53.3}=0.92 \times 7.3 \\
& t=6.7
\end{aligned}
$$


INTERNATIONAL JOURNAL OF ACADEMIC RESEARCH IN BUSINESS AND SOCIAL SCIENCES Vol. 8, No. 9, Sept. 2018, E-ISSN: 2222-6990 @ 2018 HRMARS

Degree of Freedom (DF) $=n-2=10-2=8$ at $0.05 \%=$ table value will be 2.3 